\title{
The public health benefits of urban sanitation in low and middle income countries
}

Sandy Cairncross

sandy.cairncross@lshtm.ac.uk

Professor of Environmental Health, London School of Hygiene and Tropical Medicine, Keppel St, London WC1E 7HT, United Kingdom

Abstract

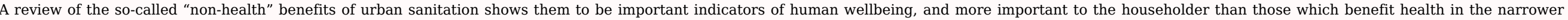
sense of preventing disease. The health benefits are surprisingly difficult to measure, but recent advances suggest that they are greater than previously thought.

\section{Keywords: Sanitation health excret}

\section{Defining interventions and benefits}

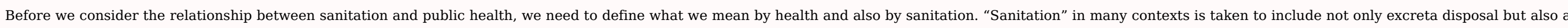

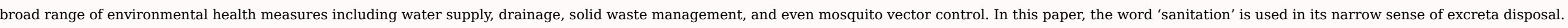

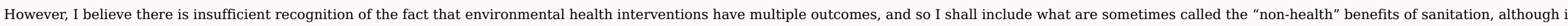

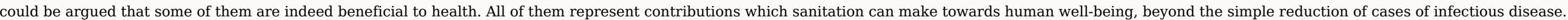

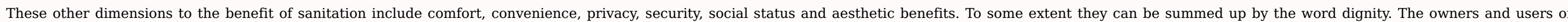

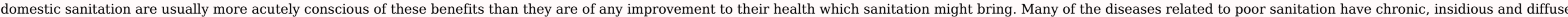

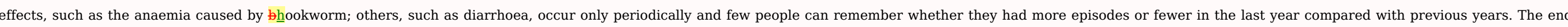

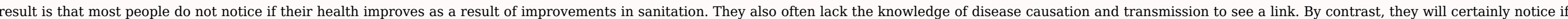
after years of defecation in the open after dark, they are able to practiese it in a secure private cubicle with a roof.

\section{Gender}

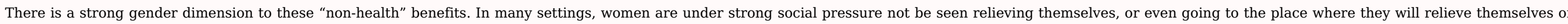

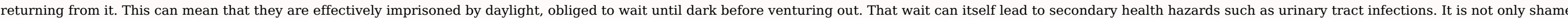

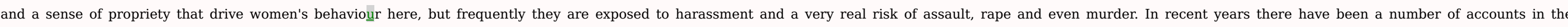
international news media of the murder of young women in India who were on their way to a defecation area.

\subsection{Gender-based violence}

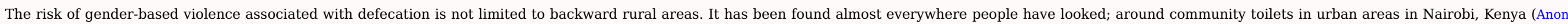

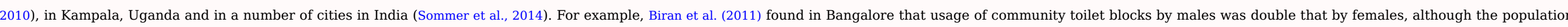

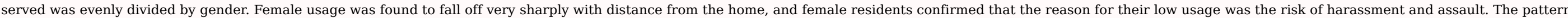
was the same, whatever the arrangements made for the management of the toilet block.

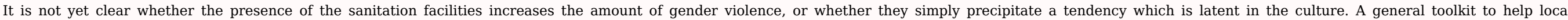

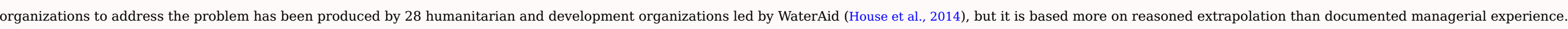




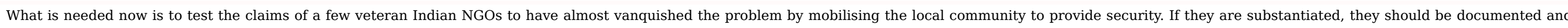
the NGOs asked to provide training to staff of some of the other NGOs promoting shared, communal or collective sanitation.

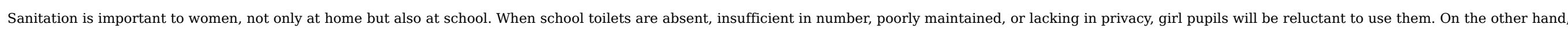

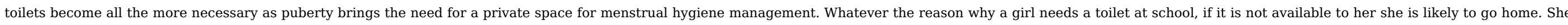

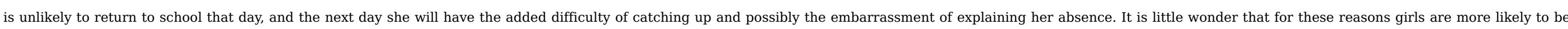

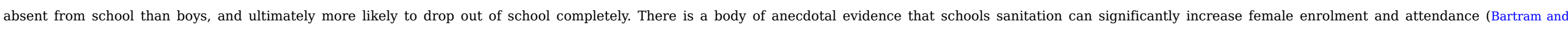
Cairncross, 2010). Few curriculum improvements could obtain that result.

\subsection{Significance of "non-health" benefits}

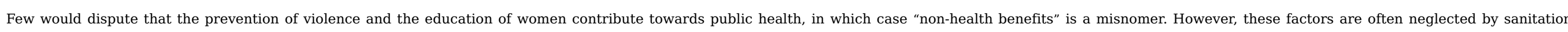

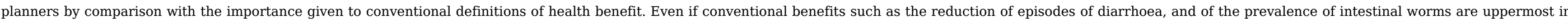
the minds of decision-makers, it is essential to remember that they will not count for much in the minds of local people, in persuading them to adopt sanitation (Cairncross, 1992; Jenkins, 1999).

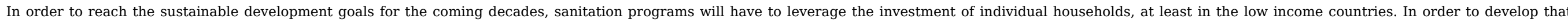
process, we need to learn much more about what makes sanitation attractive to ordinary people. Studying the so-called "non-health" benefits is a step in that direction.

\section{Health benefits}

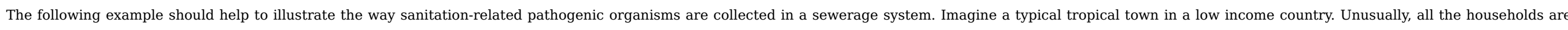

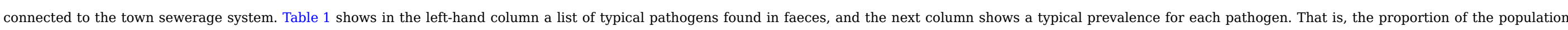

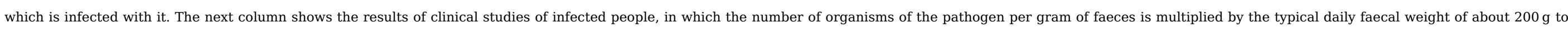
give the total number excreted daily.

Table 1 Possible concentration of pathogens in wastewater from a tropical town.

alt-text: Table 1

Source: Feachem et al. (1983).

\begin{tabular}{|c|c|c|c|}
\hline Pathogen & Prevalence of infection (\%) & Total daily per infected person & Concentration per litre of sewage \\
\hline Enteroviruses & 5 & $10^{8}$ & 5000 \\
\hline Salmonella & 7 & $10^{8}$ & 7000 \\
\hline Shigella & 7 & $10^{8}$ & 7000 \\
\hline Vibrio cholerae & 1 & $10^{8}$ & 1000 \\
\hline Entamoeba histolytica & 30 & $10^{7}$ & 3000 \\
\hline Ascaris & 60 & $10^{6}$ & 600 \\
\hline Hookworms & 40 & $10^{5}$ & 40 \\
\hline S. mansoni & 25 & $4 \underline{x} * 10^{3}$ & 1 \\
\hline Taenia saginata & 1 & $10^{6}$ & 10 \\
\hline Trichuris & 60 & $2 x+10^{5}$ & 120 \\
\hline
\end{tabular}


${ }^{\text {a }}$ Assumes $90 \%$ die-off in sewer system, septic tanks etc.

\section{1 "Sanitary hydrology"}

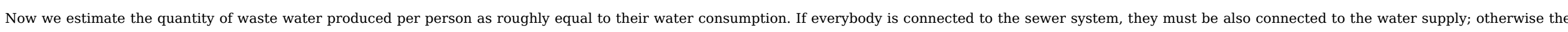

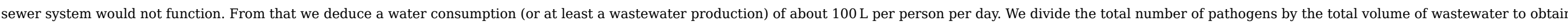

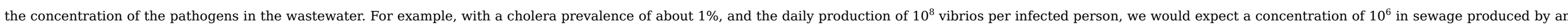

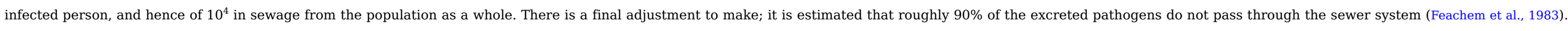

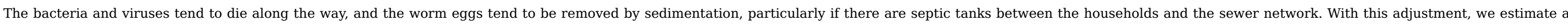
concentration of $10^{3}$ vibrios per litre, which corresponds to the value in the table. To summarise:

\section{Cholera vibrios holetios}

Number per infected person $10^{8}$ per patient

Detivided by water consumption $10^{6}$ per contaminated litre.

Aadjusted for prevalence $10^{4}$ per litre overall in house

Aadjusted for die-off in sewers $10^{3}$ per litre overall in sewer.

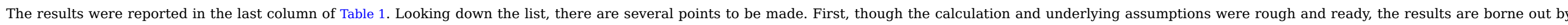

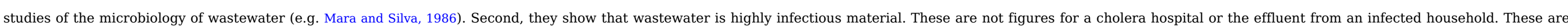

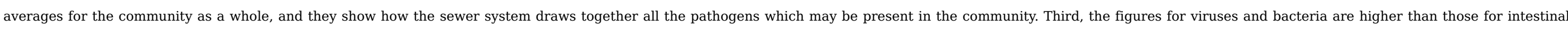

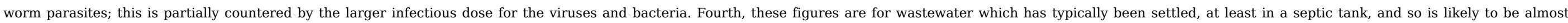
transparent. Clarity or turbidity of the wastewater is no guide to its infectiousness.

\subsection{The Bradley classification of excreta-related diseases}

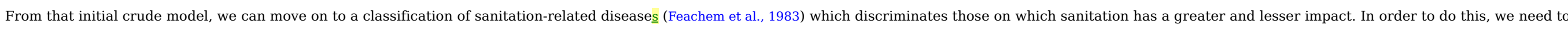

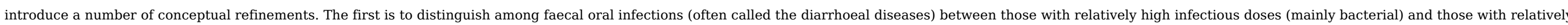

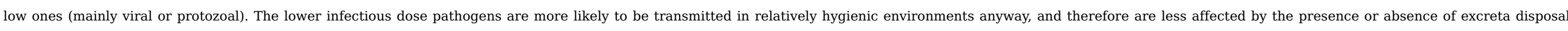
facilities.

\subsection{Animals}

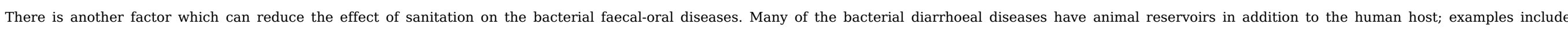

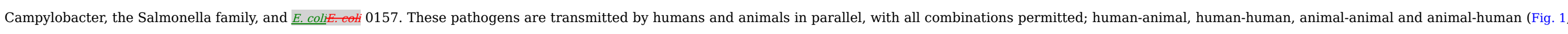
transmission in parallel).

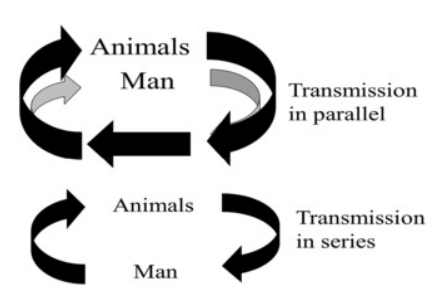




\section{alt-text: Fig. 1}

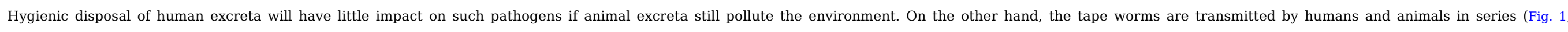
transmission in series), so that animals must be in contact with human excreta and people must eat affected meat from the animals for the disease to continue.

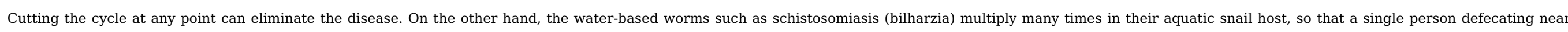

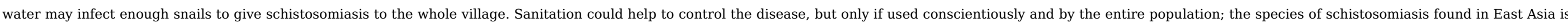
also found in various animals, so that here too, the disposal of human excreta has little impact on the disease while animals' excreta are still deposited at random.

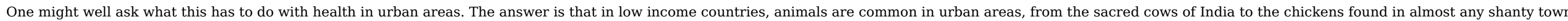
worldwide.

\section{How much disease can sanitation prevent?}

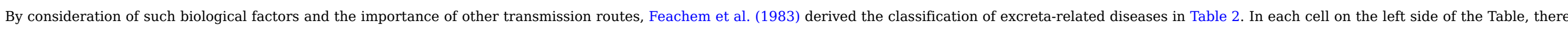
is a category of excreta-related pathogen. The constraint on rapid transmission of each arises from different biological factors.

Table 2 The Bradley classification of excreta-related infections.

\section{alt-text: Table 2}

Source: Feachem et al. (1983).

Disease group

Impact of sanitation

Non-bacterial faeco-oral

\section{Negligible}

Bacterial faeco-oral:

Slight to moderate

Soil-transmitted worms

Great

Beef \& pork tapeworms

Great

Water-based worms

Moderate

Insect vector (flies, cockroaches)

Slight to moderate

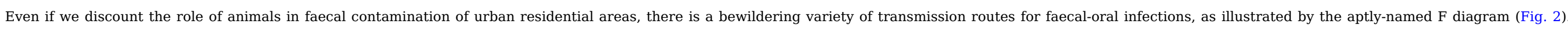

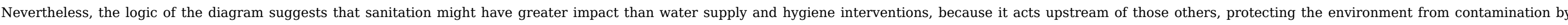

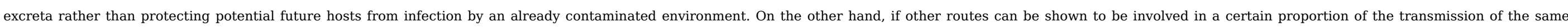

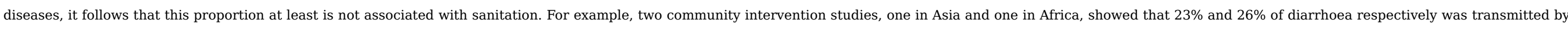

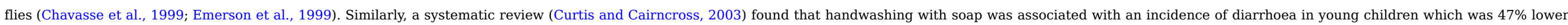
than otherwise. 


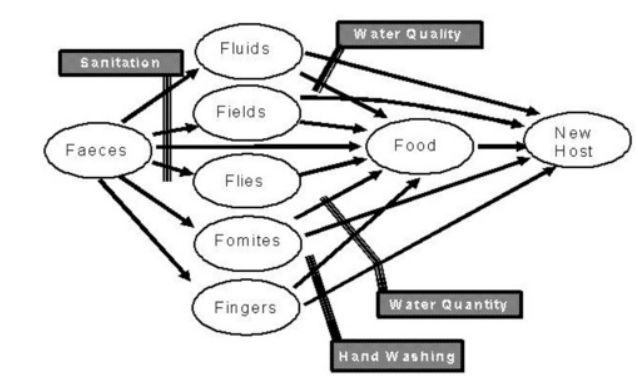

Fig. 2 The F diagram.

Note: The F-diagram shows the main transmission routes (ovals) for faecal-oral infections, and the role of water, sanitation and hygiene interventions (rectangles) in blocking those routes. Source: adapted from Wagner and Lanoix (1958), alt-text: Fig. 2

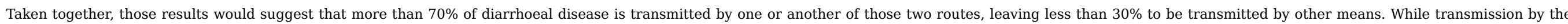

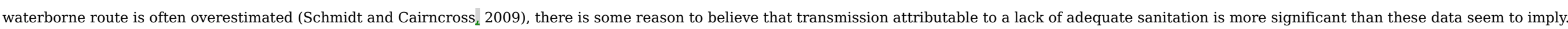

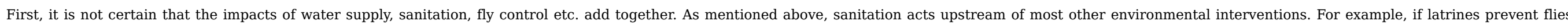
from having contact with excreta, they will reduce transmission by the fly-borne route as well as by reducing human contact with excreta.

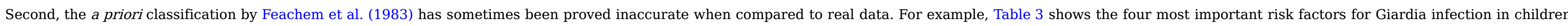

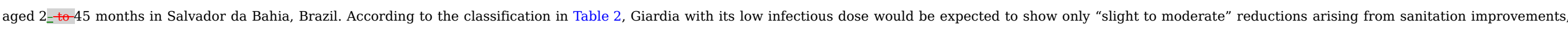

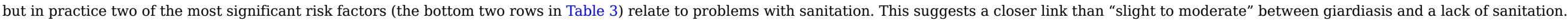

Table 3 Four most significant risk factors for Giardia infection in young children; Salvador da Bahia, Brazil.

alt-text: Table 3

Source: Prado et al. (2003) Epidemiol. Infect. 131(2): 899-906

\begin{tabular}{|c|c|}
\hline Risk factor & $\begin{array}{c}\text { Odds Ratio } \\
(95 \% \text { CI) }\end{array}$ \\
\hline № of children in family $<5$ years & $\begin{array}{l}2.08 \\
(1.32-3.27)\end{array}$ \\
\hline Solid waste not collected & $\begin{array}{l}1.97 \\
(1.22-3.16)\end{array}$ \\
\hline Presence of visible sewage near house & $\begin{array}{l}1.85 \\
(1.16-2.96)\end{array}$ \\
\hline Absence of a toilet & $\begin{array}{l}2.51 \\
(1.33-4.71)\end{array}$ \\
\hline
\end{tabular}

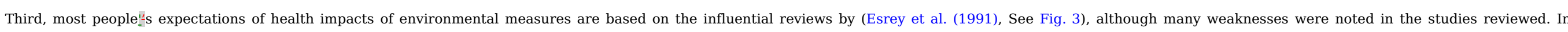

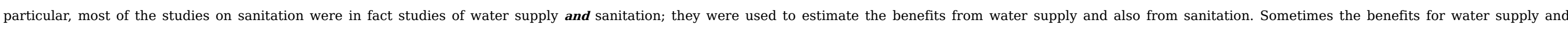

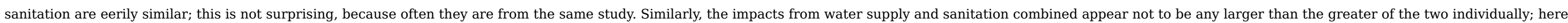
also it is likely that we have one set of studies compared with itself. 


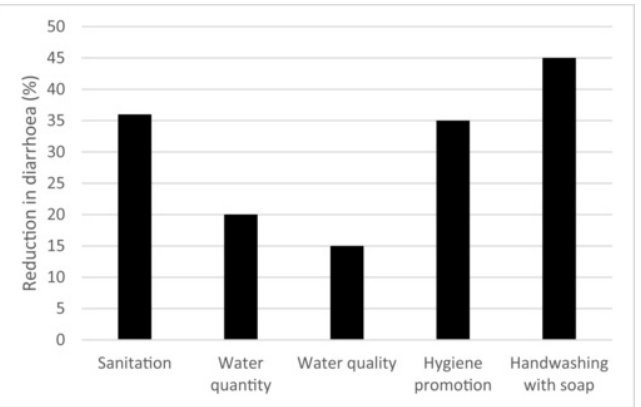

Fig. 3 Effects of improved water supply, sanitation and hygiene on diarrhoea in young children according to reviews around the turn of the century.

Sources: Sanitation and water supply: Esrey et al. (1991); Hygiene promotion: Huttly et al. (1997); Handwashing with soap Curtis and Cairncross (2003)!

\section{alt-text: Fig. 3}

\section{Confounding}

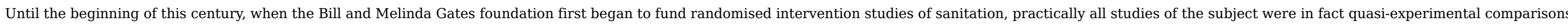

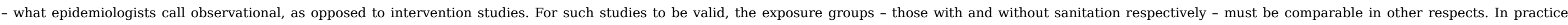

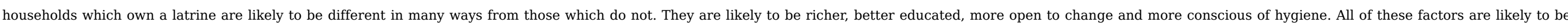

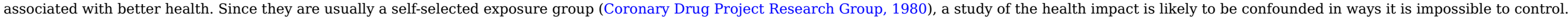

This can be illustrated with two sets of data, one from Bangladesh (Table 4) and the other from Brazil.

Table 4 'Determinants' of good hand washing among 90 rural Bangladeshi women.

alt-text: Table 4

Source: Hoque et al. (1995).

\begin{tabular}{|c|c|c|c|}
\hline \multicolumn{4}{|c|}{ Observed hand washing behaviour after defecation } \\
\hline & Good & Poor & Rel. rate $(95 \% \mathrm{CI})$ \\
\hline \multicolumn{4}{|c|}{ Own sanitary latrine used } \\
\hline yes & 22 & 11 & $1.73(1.15=-2.59)$ \\
\hline no & 22 & 35 & \\
\hline \multicolumn{4}{|c|}{ Owns agricultural land } \\
\hline yes & 36 & 24 & $2.25(1.20=-4.22)$ \\
\hline no & 8 & 22 & \\
\hline \multicolumn{4}{|c|}{ Believes that washing hands prevents diseases } \\
\hline yes & 26 & 27 & $1.01(0.66=-1.55)$ \\
\hline no & 21 & 18 & \\
\hline
\end{tabular}

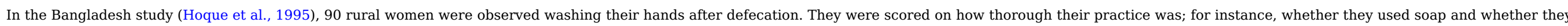

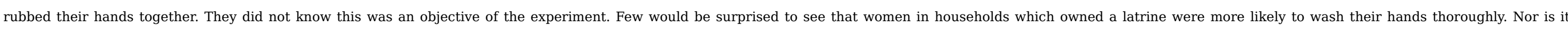




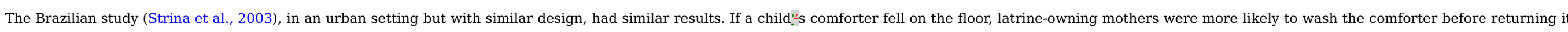

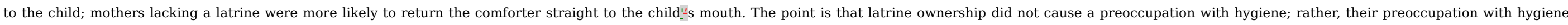
impelled some families to install a latrine.

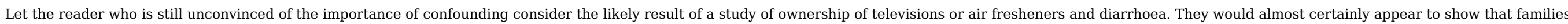
with televisions and air fresheners suffer from less diarrhoea, although there is no evidence that a TV or an air freshener can protect anyone from food poisoning!

\subsection{The travail of trials}

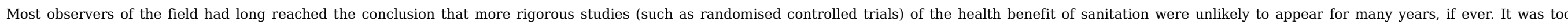

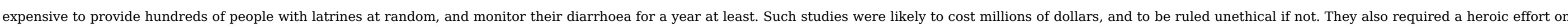
the implementation of the intervention with a view to being able to say, if little or no benefit was found, that the fault was in the intervention and not in the experimental design.

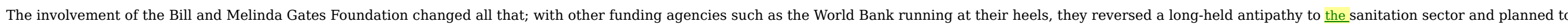

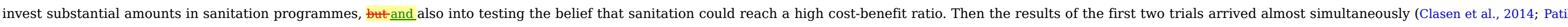

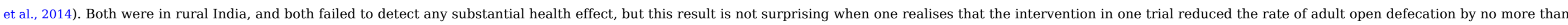

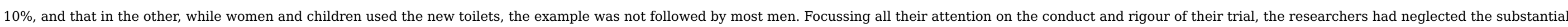

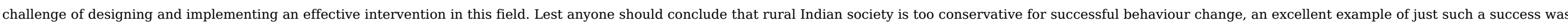

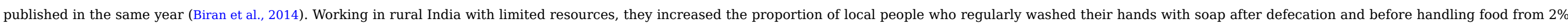
to $37 \%$ or more.

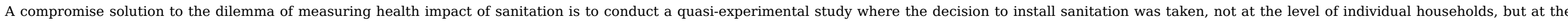

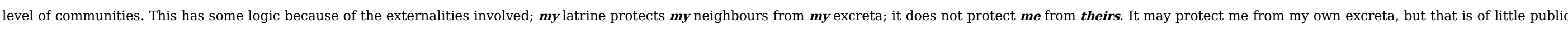
health impact because pathogens are likely to be passed among family members anyway. This was the approach taken by Moraes et al. (2003), who compared three groups of three favelas in Brazil.

\subsection{2: Moraes; comparing favelas in Brazil}

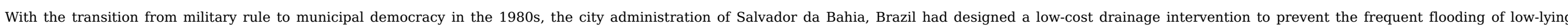

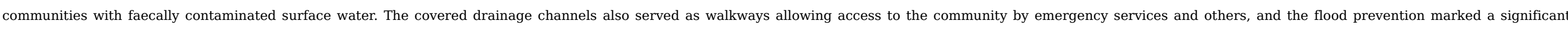

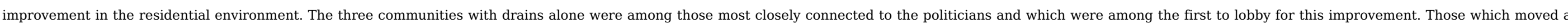

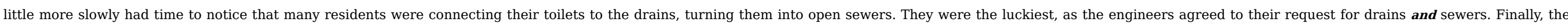

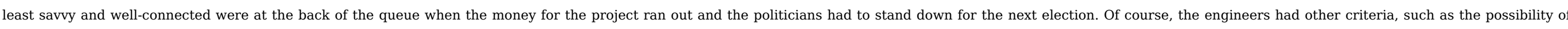

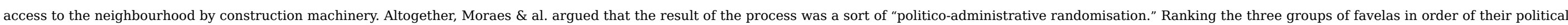
influence, we have:

1. Drains

2. Sewers and drains

3. No intervention; control

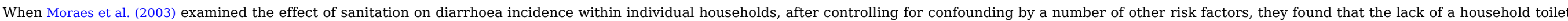




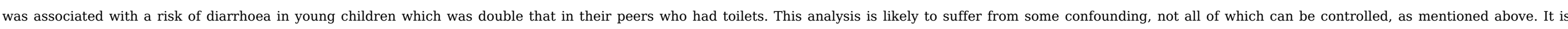

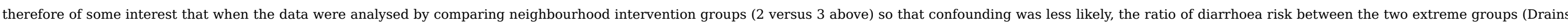
and sewers versus no intervention) was not two to one, but three to one.

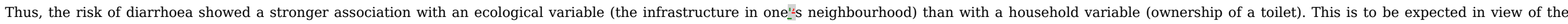
externalities mentioned in Section 5.1 .

Moreover, this relatively large ratio would suggest that sanitation has much greater impact on people_-s health than had previously been supposed.

\subsection{The big project; before and after}

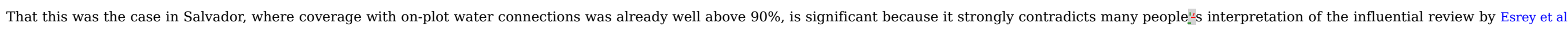

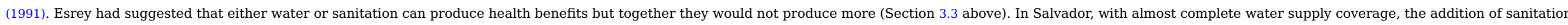
seems to offer benefits much larger than the Esrey review suggested.

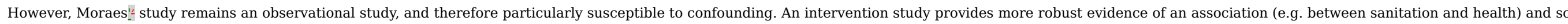

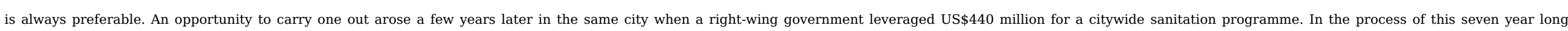
sewerage construction programme, the proportion of the city_s 2.4 million population with access to sewers increased from $26 \%$ to $80 \%$.

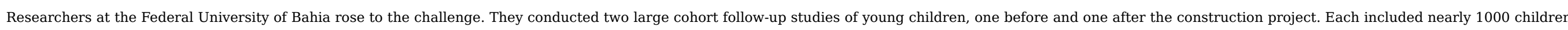
under five, who lived in 24 sentinel areas chosen to represent conditions around the city, and who were followed for nearly a year. The results are shown in Table 5 . To summarise:

- Diarrhoea rates had fallen by $21 \%$ overall, and by twice that in the areas of the city with the highest initial risk of diarrhoea;

- Adjustment for confounders hardly alters this, thus confirming the finding;

- Adjustment for the proportion of households with project sewers in the neighbourhood made the effect disappear; adjusted PR $~ 1.0$.

Table 5 Diarrhoea Prevalence Ratios (PR) after/before the intervention.

\section{alt-text: Table 5}

Source: Barreto et al. (2007).

\begin{tabular}{|c|c|c|}
\hline & Total population & Areas with high baseline risk ${ }^{a}$ \\
\hline Prevalence ratios (PR) after/before project & PR $(95 \%$ CI $)$ & PR $(95 \%$ CI $)$ \\
\hline Unadjusted & $0.79(0.75=-0.82)$ & $0.58(0.55=-0.61)$ \\
\hline Adjusted for baseline sewerage and confounders & $0.78(0.74--0.81)$ & $0.57(0.54=-0.61)$ \\
\hline Adjusted as above, and for neighbourhood coverage with project sewers & $1.02(0.90--1.16)$ & $1.02(0.90=-1.16)$ \\
\hline
\end{tabular}

Note that: Percentage reduction in diarrhoea $=(1-\mathrm{PR}) \times 100$.

a 12/24 study neighbourhoods $>8$ diarrhoea days/child. (In footnote to Table 5, delete period after "child". )-year,

Of course this did not mean that the impact was not real; only that the variation in the impact between different parts of the city could be explained by the variation in coverage with sewers.

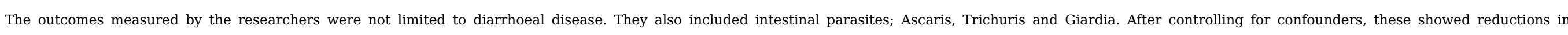

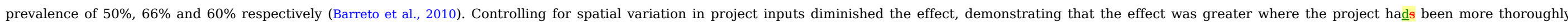




\section{Defeating poverty as well as disease}

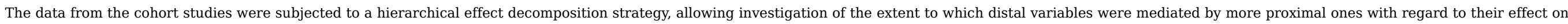

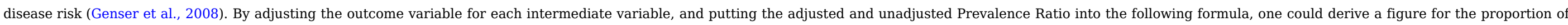
the overall association which was mediated by each intermediate variable:

Mediating Proportion $=\left(\mathrm{PR}_{\text {adj }}-\mathrm{PR}_{\text {unadj }}\right) /\left(1-\mathrm{PR}_{\text {unadj }}\right)$

where $\mathrm{PR}_{\mathrm{adj}}$ and $\mathrm{PR}_{\text {unadj }}$ referred to adjusted and unadjusted prevalence ratios respectively.

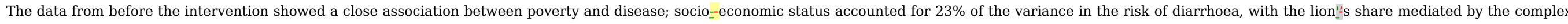

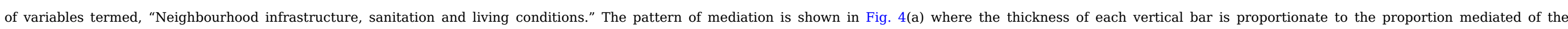
association between diarrhoea risk and socioeconomic status (In Fig 4, the A and B to label the two figures should be in lower case.).

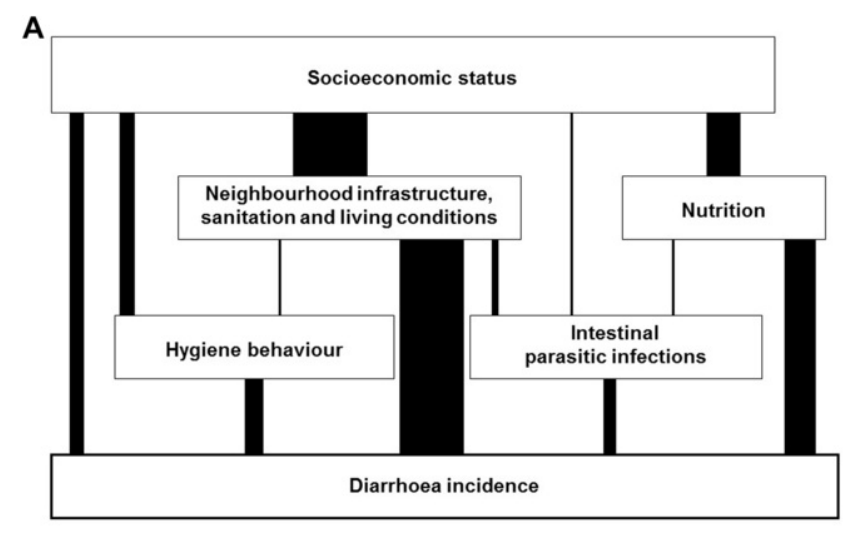

B

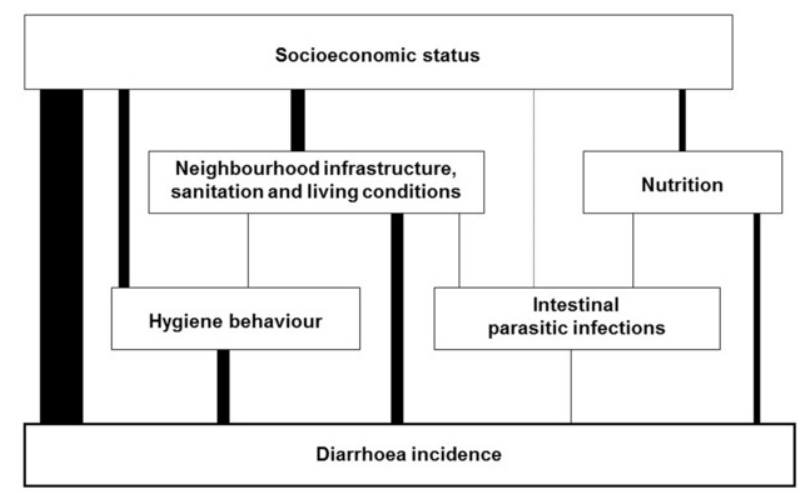

Fig. 4 (a) Intermediate variables in Salvador da Bahia before implementation of the sanitation project. (b) The same analysis performed on the data collected after completion of the intervention. Source: Bartram and Cairncross (2010); data from Genser et al. (2008)) alt-text: Fig. 4 


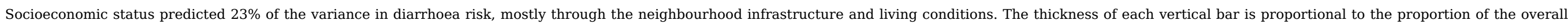
association which is mediated by that route.

Now, if we turn to the same analysis performed after the completion of the project, the difference is quite striking

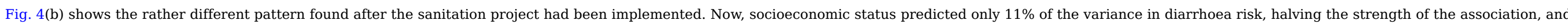

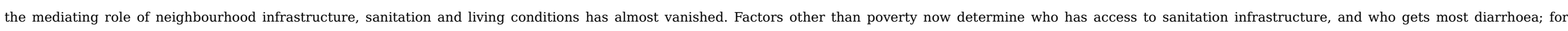

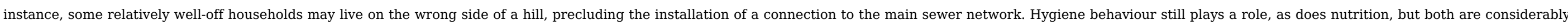

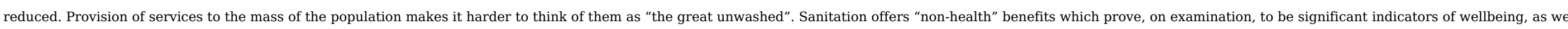

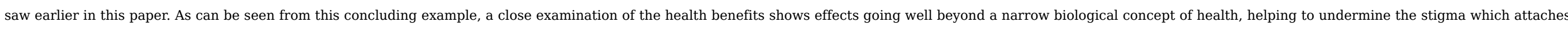
to the poor by the linking of poverty and disease.

\section{Concluding remarks}

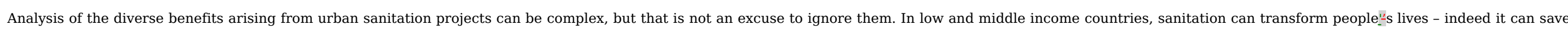

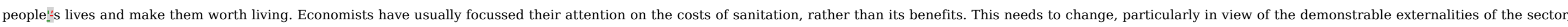
and the increasing reliance by governments and municipalities upon leveraged investment by the households themselves, rather than on more conventional sources of municipal finance.

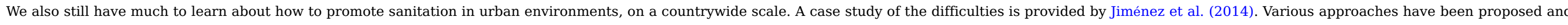

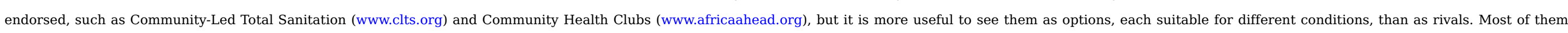

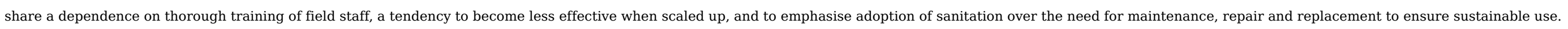

\section{Funding}

This research did not receive any specific grant from funding agencies in the public, commercial, or not-for-profit sectors.

\section{Appendix A. Supplementary data}

Supplementary data related to this article can be found at https://doi.org/10.1016/j.jup.2018.03.001.

\section{References}

Anon, Risking Rape to Reach a Toilet; Women's Experiences in the Slums of Nairobi, Kenya, AFR 32/006/20102010, Amnesty International; London.

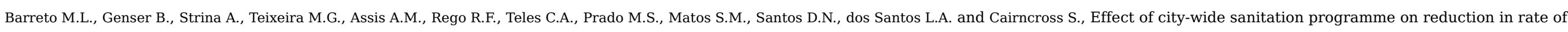
childhood diarrhoea in northeast Brazil: assessment by two cohort studies, Lancet 370 (9599), 2007, 1622-1628.

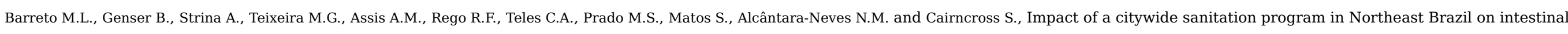
parasites infection in young children, Environ. Health Perspect. 118 (11), 2010, 1637-1642, https://doi.org/10.1289/ehp.1002058.

Bartram J. and Cairncross S., Hygiene, sanitation, and water: forgotten foundations of health, PLoS Med. 7 (11), 2010, https://doi.org/10.1371/journal.pmed.1000367, e1000367.

Biran A., Jenkins M.W., Dabrase P. and Bhagwat I., Patterns and determinants of communal latrine usage in urban poverty pockets in Bhopal, India, Trop. Med. Int. Health 16 (7), 2011, 854-862, https://doi.org/10.1111/j.1365-3156.2011.02764.x.

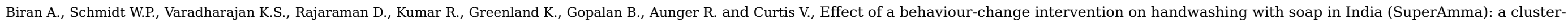
randomised trial, Lancet Glob Health 2 (3), 2014, e145-e154, https://doi.org/10.1016/S2214-109X(13)70160-8, Epub 2014 Feb 27. Erratum in: Lancet Glob Health. 2014 Apr;2(4):e207. 
Cairncross S., Sanitation and Water Supply: Practical Lessons from the Decade, Water and Sanitation Discussion Paper No. 91992, The World Bank; Washington DC.

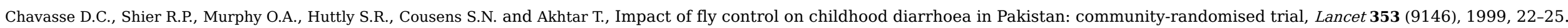

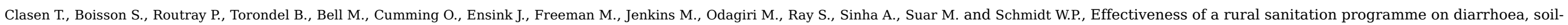

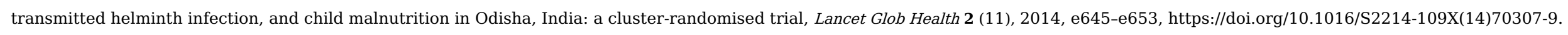

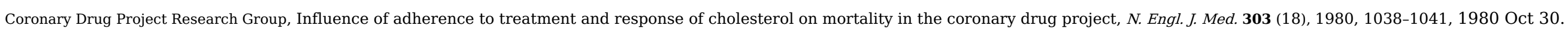

Curtis V. and Cairncross S., Effect of washing hands with soap on diarrhoea risk in the community: a systematic review, Lancet Infect. Dis. 3 (5), 2003, 275-281.

Emerson P.M., Lindsay S.W., Walraven G.E., Faal H., Bøgh C., Lowe K. and Bailey R.L., Effect of fly control on trachoma and diarrhoea, Lancet 353 (9162), 1999 , $1401-1403$.

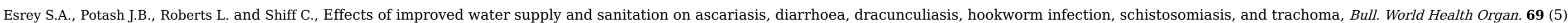
$1991,609-621$.

Feachem R.G., Bradley D.J., Garelick H. and Mara D.D., Sanitation and Disease; Health Aspects of Excreta and Wastewater Management, 1983, John Wiley \& Sons; London.

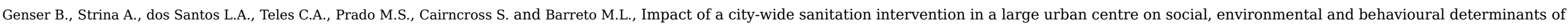
childhood diarrhoea: analysis of two cohort studies, Int. J. Epidemiol. 37 (4), 2008, 831-840, https://doi.org/10.1093/ije/dyn101.

Hoque B.A., Mahalanabis D., Alam M.J. and Islam M.S., Post-defecation handwashing in Bangladesh: practice and efficiency perspectives, Publ. Health 109, 1995, 15-24.

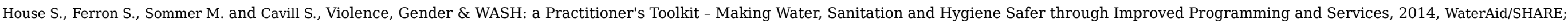
London, UK, (violence-wash.lboro.ac.uk/toolkit).

Huttly S.R., Morris S.S. and Pisani V., Prevention of diarrhoea in young children in developing countries, Bull. World Health Organ. 5 (2), 1997, 163-174.

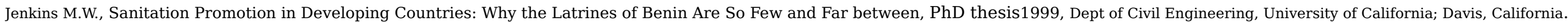
Jiménez A., Mtango F.F. and Cairncross S., What role for local government in sanitation promotion? Lessons from Tanzania, Water Pol. 16, 2014, 1104-1120.

Mara D.D. and Silva S.A., Removal of intestinal nematode eggs in tropical waste stabilization ponds, J. Trop. Med. Hyg. 89 (2), 1986, 71-74.

Moraes R.S., Cancio J.A., Cairncross S. and Huttly S.R.A., Impact of drainage and sewerage on diarrhoea in poor urban areas in Salvador, Brazil, Trans. R. Soc. Trop. Med. Hyg. 97, 2003, 153-158.

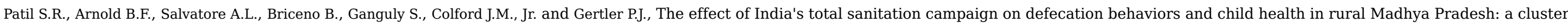
randomized controlled trial, PLoS Med. 11 (8), 2014, https://doi.org/10.1371/journal.pmed.1001709, eCollection 2014 Aug.: e1001709.

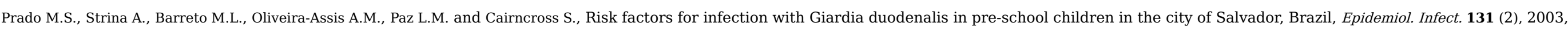
899-906.

Sommer M., Ferron S., Cavill S. and House S., Violence, gender and WASH: spurring action on a complex, underdocumented and sensitive topic, Environ. Urbanization 27 (1), 2014, 105-116,

https://doi.org/10.1177/0956247814564528.

Strina A., Cairncross S., Barreto M.L., Larrea C. and Prado M.S., Childhood diarrhea and observed hygiene behavior in Salvador, Brazil, Am. J. Epidemiol. 157 (11), $2003,1032-1038$.

Wagner E.G. and Lanoix J.N., Excreta Disposal for Rural Areas and Small Communities, 1958, World Health Organization; Geneva.

\section{Appendix A. Supplementary data}

The following is the supplementary data related to this article: 


\section{Highlights}

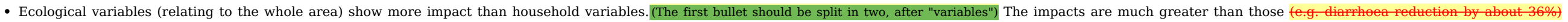
suggested in the systematic reviews by Esrey et al. (1991).

- Excreta-related diseases can affect children's physical and cognitive development.

- We know very little about how these infections and outcomes interact.

\section{Queries and Answers}

Query: Highlights should only consist of "125" characters per bullet point, including spaces. The highlights provided are too long; please edit them to meet the requirement. Answer: Ecological variables (relating to the whole area) show more impact than household variables.

The impacts are much greater than those suggested in the systematic reviews by Esrey et al. (1991).

Excreta-related diseases can affect children's physical and cognitive development.

We know very little about how these infections and outcomes interact.

Attachments: Highlights.docx

Query: Please check the paragraphs below "Cholere vibrios" and correct if necessary.

Answer: Done

Query: Please check the layout of Table 4 and correct if necessary.

Answer: Done

Query: Please check the figure caption 4 and correct if necessary.

Answer: Labels a and b for the two parts of the Figure should be in lower case, and preferably in brackets.

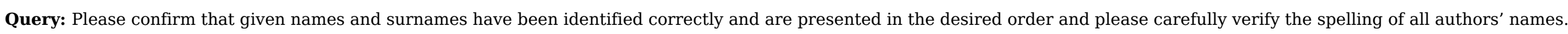

Answer: Yes

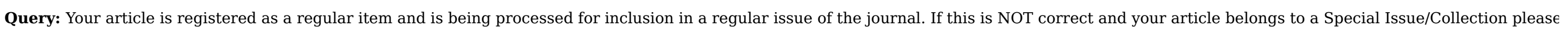
contact k.kunchala@elsevier.com immediately prior to returning your corrections.

Answer: Yes it will be in a special issue of Utilities Policy edited by prof Claude Menard of the Universite de Paris. 